\title{
Chinese Unprecedented Move Towards Its One-Belt -One- Road Initiative (OBOR): Unfolding the Mythic Realities of Chinese Sphere of Legal Influence in the International Legal Order
}

\author{
Ayalew Abate Bishaw ${ }^{1,2^{*}} \quad$ Muhammad Bilawal Khaskheli ${ }^{1 *}$ \\ Doctoral Candidate in Law, Guanghua Law School, Zhejiang University, 51 Zhijiang Road, Hangzhou, Zhejiang \\ Province, 310008 , China \\ Assistant professor in law, Debre markos University law school Ethiopia
}

\begin{abstract}
This article explores that while the ever registered vibrant economic development in China radiates from the legal system, the legal system has not been well cherished and praised. Therefore, the purpose of this essay is to unleash and enlighten the sphere of Chinese legal influence to the global legal order by taking OBOR as one particular example. It touches main conceptual frameworks to do with road jurisprudence and steps down to a conclusion by suggesting further deep investigation to be made.
\end{abstract}

Keywords: One -Belt- One- Road Initiative, international legal order, China and Road jurisprudence DOI: $10.7176 / \mathrm{IAGS} / 70-03$

Publication date:March $31^{\text {st }} 2019$

\section{Introduction}

China has been the leading developing state, known for long period, in defending and/or representing the developing countries approach/stand to the international and western-dominated global legal-order regarding sovereignty, human right, and environment ${ }^{1}$. It has been a voice for the voiceless developing countries because of its keen interest of self-determination and right to development. ${ }^{2}$ Its strong position of adhering to its own philosophies and thoughts and principle of non-interference has been supported by the third world countries. Best accomplishing its internal homework with less than four decades ${ }^{3}$, China has come now to be the world's leading and huge economy with the projected sphere of legal influence on the international legal order. Nevertheless, no one has ever made this topic. The OBOR initiative and the corresponding road jurisprudence that follows signal many of the sphere of influence that one doesn't well appreciate about ${ }^{4}$. The East where China is its symbol, after 500 hundred western predominances has started its strategic move to influence the legal and other international affairs.

This paradox was retreated as "in China's Orbit" by renowned law and economics American scholar, Niall Ferguson ${ }^{5}$. Most African, Latin America and the Asian States are almost praising the Chinese government approach in regulating its internal affairs and strategic move towards achieving the goals to their peoples' common destiny of civilization and/or development. Now China has taken a major responsibility in the climate change negotiation ${ }^{6}$. Being in the developing country category it takes the huge responsibility ${ }^{7}$. Unlike US, China is committing itself for the climate change deal in Parris and now in Denmark.

Among other things that China has been/is doing, we want to focus and unleash on the OBOR initiative so much so that, on the bases of which we could clear out and reflect on points of Chinese sphere of legal influence ${ }^{8}$ in the global legal order. We want to underscore, among other things on the jurisprudential implication of the OBOR initiative to show that Chinese sphere of legal influence on the global legal order is reflected through.

We used this road development initiative in order to show the Chinese sphere of global legal influence

\footnotetext{
${ }^{1}$ sanna kopra (2016), great power management and china's responsibility in international climate politics, jcir: vol. 4, no. 1 (2016) pp. $20-44$.

${ }^{2}$ xinhua, the right to development: china's philosophy, practice and contribution, the state council information office of the people's republic of china december 2016

naill ferguson, in china's orbit, the wall street journal, november 18, 2010 last accessed in september 2016 http://www.wsj.com/articles/sb10001424052748704104575622531909154228, in this essay he argued that after 500 years of western predominance, the world is tilting back to the east.

${ }^{4}$ it is very clear that we reach each other through road infrastructure. now it has come to be easy to access each other also because of internet technology. therefore the significant contribution of road construction shall be underlined. road is a means on which we can move on and transfer technology. it is a means we can bring exchange of ideas and practices. it is also the way to take advantage of something and we can influence legal system of countries. road jurisprudence is really untouched area that needs further consideration and is really innovative in the legal discourse. china through constructing such big project is at same time transferring its brand and the corresponding legal issues are not simple too

5 ibid

${ }^{6}$ see supra note 1

7 id

${ }^{8}$ readers shall come very clear that i don't frame the title as sphere of dominance but influence because chinese are always resistance to the world domination but co-operation and co-existence. they pledge every time that they don't work for dominance but for common goal and objective.
} 
because we presuppose that the Chinese legal system has contributed for the coming into the birth of the initiative itself. This grand project has not emerged and come into operation without the contribution from the Chinese legal system. This analysis is not, indeed, without the jurisprudential support and one can refer to the "mirror thesis theory" "that articulate law as a reflection of society. Therefore when we say the OBOR initiative $^{2}$, it is on our humble understanding that it reflects best Chinese legal influence to global legal order ante and post scenario.

China since 2013 has developed and presented to the world the unprecedented road initiative that could connect more than 70 percent of the total world population ${ }^{3}$. This unprecedented road initiative, with the embedded objective of avoiding trade barriers, signals much more things than we can reasonably guess and will be century's social, cultural, political, technological, legal and economical plat forum. This road is not a simple initiative but is with huge and bold jurisprudential sphere of influence in the international legal order ${ }^{4}$. China, we believe has given legal scholars difficult but potential homework to reconstruct our jurisprudential thoughts and creating new legal theories too ${ }^{5}$. The right to development (that China has been insisting on reflecting the representing developing countries view) and Chinese human right philosophy, I hope has now ripe to regain ear at an international forum. Their strong believe that development is for the sake of human dignity has now started playing global importance once we look deep into this road initiative ${ }^{6}$. Connecting physically disintegrated and dispersed countries and peoples are more than the right to access to information per se. Now you may go and see what you hear on the internet probably with less cost compared to the more expensive air transport and others. Chinese overseas investment and the principle of peaceful co-existence and cooperation have given birth of its own foundation for the global alliance and support to common destiny as Chinese always preaches the world about. $^{7}$

Thus, this succinct paper is meant to unreveal the state of projected legal influence that China could pose to the international legal order which may touch upon trade, investment, socio-cultural and legal aspects. By this author's belief, the OBOR initiative ${ }^{8}$ is one big practical step best could describe the sphere of legal influence as used herein this context. For the sake of clarity, the scope is delineated to focus on the road jurisprudence, cooperation and sovereignty, right to development, investment and dispute settlement and some more related issues.

\subsection{A Brief Description of OBOR Project and International Legal Order}

OBOR project is the top most unprecedented big project that one country has brought into the whole world. It connects around more than 70 countries of the world9. Otherwise expressed more than 70 countries have agreed by the initiative brought up by a single country. It means that between China, the initiator and in fact the project operator and other countries consensus have been reached and international deal has succeeded. It has got international recognition and acceptance between parties that consented for its operation. If we see most of the agreements at international level, most don't have such big member exceeding 70 countries. This implies that China has able to influence and develop agreement with these countries that reflects its powerfulness in bringing the world together towards development. 10 This shows that China influences the majority of the World population and its potential in the international legal order is vivid. In fact China represents nearly 20 percent of the global population 11 and its power in challenging the international legal order is assumed.

\footnotetext{
${ }^{1}$ as per this theory law is reflection of society.

2 obor initiative is now changed into green belt and road initiative in order for indicating the sustainability. https://wedocs.unep.org/bitstream/handle/20.500.11822/25178/un\%20environment $\% 20$ belt $\% 20$ and $\% 20$ road $\% 20$ strategy $\% 20$ final.pdf?seque nce $=38 \&$ isallowed $=y$ last accessed on 20 nov 2018 .

${ }^{3}$ see the belt and road initiative: 65 countries and beyond may 2016 ,

http:/china-trade-research.hktdc.com/business-news/article/the-belt-and-road-initiative/the-belt-and-road-initiative-countryprofiles/obor/en/1/1x000000/1x0a36i0.htm https://www.fbicgroup.com/sites/default/files/b\%26r_initiative_65_countries_and_beyond.pdf last accessed on 15 dec. 2018

${ }^{4}$ see supra note 4

${ }^{5}$ there are bunch of scholarly articles on obor initiative. one can simply write obor on internet and prove the existing booms. it has come to be the platform for scholars to discuss about china. with one simple click more than 20 urls will be viewed.

${ }^{6}$ this is because most developing countries are following chinese development trend (political economy). one may take ethiopia as good example.

${ }^{7}$ see chinese foreign policy document which is founded basically on this principles.

${ }^{8}$ ibid

9 peter cai (march 2017) understanding china's belt and road initiative, lowy institute for international policy, 2017 https://www.lowyinstitute.org/sites/default/files/documents/understanding $\% 20$ china $\%$ e $2 \% 80 \% 99$ s $\% 20$ belt $\% 20$ and $\% 20$ road $\% 20$ initiative_we b_1.pdf last accessed on 18 dec. 2018

${ }^{10}$ it seems in recognition of such state of fact that the undp consider obor initiative as a new means to transformative global governance to sustainable development. see from:

http://www.cn.undp.org/content/dam/china/docs/publications/undp-ch-ggr\%202017.pdf last accessed on $18 \mathrm{dec} 2018$

${ }^{11}$ as per the report from https://tradingeconomics.com/china/population the population of china represents 19.48 percent of the world's total population which arguably means that one person in every 5 people on the planet is a resident of china. this page provides - china population - actual values, historical data, forecast, chart, statistics, economic calendar and news. china population - actual data, historical chart and
} 
Following the OBOR initiative in China has concluded various agreements with countries the project touches1. Thos countries that the project doesn't have a touch are also re-negotiating with China for the projects extension to them2. This has a very clear implication for the development of legal relation between the countries connected through the project. Through agreement of countries to the project they are concluding bilateral or multilateral agreement and further following the agreement various additional agreements are expected relating to the projects implementation which may include employment, human right, environment, dispute settlement, agreement of cooperation etc that has its own international legal repercussions. Its influence on the international legal order therefore is tremendous3. Through negotiations and dispute settlement all the way the project reaches Chinese legal understanding (philosophies) and practices are going to be reflected. Whether the issue is settled between parties in agreement or reaches at international tribunals doesn't matter. This is because still there (at the international tribunal) Chinese law and Chinese practice will be considered. The initiative implies therefore the interaction of legal systems of countries of the project with legal systems of China that paves the way for Chinese to challenge international legal order.

\subsection{Chinese OBOR Initiative and the Road Jurisprudence}

The road infrastructure is the pillar of all development that every nation and human being aspires to meet. ${ }^{4}$ It is the cornerstone of all the human rights to enjoy ${ }^{5}$. The rights to movement and other human rights can't be successfully exercised without access to the road $^{6}$. One can imagine the importance of road to exercise our right to basic needs and beyond pausing himself for a movement and think about what would have been existed without this road infrastructures. You can't imagine the world without a road as important.

What Chinese OBOR initiative would bring is pretty clear and how it will be seen relating to the servitude, nations servitude right to best access the world vis-a-vis sovereignty has a lot to imply and discussed. This is one innovation that the Chinese initiative has brought us relating to our jurisprudence. Here this project is going to be implemented throughout countries that it touches in. Thus how is it going to be implemented, what and whose companies, and other operational level management issues all have legal repercussion. Which country law and which court, whether international or national laws are issues that the road initiative has brought to us. It is different from mere BIT because the effect doesn't remain between two states and may be far-reaching once it gets out of the hand of two countries. Can the traditional understanding relating to servitude work? What does servitude mean in this context are some of the basic issues need to be discussed? Whether or not Chinese have right of way in the sovereignty understanding to bring such huge project to us is also the issue to be raised relating to OBOR initiative.

The traditional understanding of servitude implies a limited right that someone has to use the land belonging to another e.g. a right of way (a path or road over private land which people are legally allowed to use) ${ }^{7}$. It can also be used in more general terms to refer to a claim or other liability attached to a piece of property. Servitudes allow people to create long-term arrangements for a wide variety of purposes, including shared land uses, maintaining the character of a residential neighborhood, commercial development, or historic property; and financing infrastructure and common facilities. ${ }^{8}$ Thus whether we use it at international and country level the concept so imply as Chinese servitude initiative would be an issue. Therefore what we can say here is that

calendar of releases - was last updated on december of 2018.

1 ibid

2 helen chin, winnie he (2016), the belt and road initiative: 65 countries and beyond may 2016 accessed from https://www.fbicgroup.com/sites/default/files/b\%26r_initiative_65_countries_and beyond.pdf as can be understood from this originally the countries were not as much as 70 and beyond. it is through negotiation and further agreement that the project expands covering some more countries.

${ }^{3}$ as may be understood from the conference held on the title "china and global governance: between the international rule of law and the international rule of power" it is very clear that china's rise into economic power has many implications in the international legal order. see from:

https://www.qmul.ac.uk/law/media/law/docs/events/china-and-global-governance-workshop-programme.pdf last accessed on 18 dec. 2018

${ }^{4}$ cschachtebeck and jm mbuya (2016), assessing the potential benefits of road infrastructure development for poverty alleviation: lessons learnt from developing economies proceedings of the 35th southern african transport conference (satchttps://www.researchgate.net/publication/304771228_assessing_the_potential_benefits_of_road_infrastructure_development_for_povert y_alleviation_lessons_learnt_from_developing_economies last accessed on 16 dec. 2018

unhr (2017), baseline study on the human rights impacts and implications of mega-infrastructure investment https://www.ohchr.org/documents/issues/development/dfi/mappingstudyonthehrriskimplications_megainfrastructureinvestment.pdf last accessed on 16 dec. 2018

${ }^{6} \mathrm{j}$. unruh, m. shalaby. 2012. road infrastructure reconstruction as a peace building priority in afghanistan: negative implications for land rights, in assessing and restoring natural resources in post conflict peace building, ed. d.jensen and s. lonergan. london: earthscan. https://www.eli.org/sites/default/files/vol.5 ch.20 unruhshalaby colorcoverpage.pdf

${ }^{7}$ pitman b. potter (2012), the doctrine of servitudes in international law, the american journal of international law, vol. 9 , no. 3 (jul., 1915 ), pp 627-641 published by: cambridge university press accessed: 16-12-2018 13:23 utc https://www.jstor.org/stable/pdf/2187098.pdf, book iii. title xxxiv. concerning servitudes and concerning water. (de servitutibus et de aqua.) bas. 58.7; d. 8.1.3. 4; inst. 2.3. https://www.uwyo.edu/lawlib/blume-justinian/ajc-edition-2/books/book3/book\%203-34rev.pdf

${ }^{8}$ zhenglimin xinhua, the right to development: china's philosophy, practice and contribution bjt 
Chinese has used to develop this kind of project with a broad spectrum on the theme that this is all foundational frameworks to exercise all the rights on earth freely. The project is great and huge importance that we have seen no country to opposes it. The legal implication of the project being lawyers' assignment for century its legal Chinese sphere of influence is very clear and predictable.

In nutshell, the authors forward their view that this initiative has brought about new Chinese perspective of understanding of rights and particularly right of access to basic infrastructure at international and international actors level. It has boldly indicated that rights to be enforced at international level owe states big assignment yet far to reach without such big practical walk and thinking. This is how the open policy framework of China can be best practiced. This is the Chinese model of development that leads human beings to well exercise their rights. It has spearheading influence for other developing countries.

\subsection{Chinese OBOR Initiative and the Right to Development}

The right to development has been the heartbeat of China in most international meetings/conferences and signals most of the time its understanding of human right as attached to development taking into account its own home context. ${ }^{1}$ China needs development for sake of its huge population collective interest than individualistic prevailed. Chinese human right approach is highly attached to the social and economic rights than civil and political rights ${ }^{2}$. It focused on collective than individual rights ${ }^{3}$. This initiative as described above is the key move forward/leap forward to the realization of development to especially third world countries including Africa (it focused on collective interest at its grand level). The cost of transportation and other expenses will be unimaginably reduced compared to the current state of being and risks minimized. It links both rich and poor countries of Africa to the other world. Thus it facilitates the free trade and other interactions between countries in line with the free trade and investment policy of different developed countries including the WTO. The Chinese legal influence will be thus vivid and its significance to the realization of human right and development.

The source of the right to development, as a legal concept, can be found traced back to and entrenched in the provisions of the Charter of the United Nations, and in the Universal Declaration on Human Rights. Through the United Nations Charter, Member States undertook to "promote social progress and better standards of life in larger freedom" and "to achieve international cooperation in solving international problems of an economic, social, cultural or humanitarian character, and in promoting and encouraging respect for human rights and for fundamental freedoms for all without distinction as to race, sex, language or religion."

This concept though existed for long as guiding principle doesn't bake bread for starved African and Asian countries. No Road no development and they were treated as backward and underdeveloped for a long period of time. The initiative has come with China as stare with big light that is development. Thus, more than the seven "roasted human right echo" of the West Chinese four-year-old baby- the OBOR initiative has penetrated deep into African's heart attracting investment and on the zeal of development. This is what we mean Chinese style of legal influence-just walking the walk and not talking the talk!

The Universal Declaration on Human Rights contains a number of elements that became central to the international community's understanding of the right to development. It attaches importance, for example, to the promotion of social progress and better standards of life and recognizes the right to non-discrimination, the right to participate in public affairs and the right to an adequate standard of living. It also contains everyone's entitlement to a social and international order in which the rights and freedoms set forth in the Declaration can be fully realized.

Notwithstanding this proposal, however, the means of realization of same was left to States whether or not capable or incapable. The means by which the international community and countries could help its realization has been weak. Thus, we believe such a big project with a big dream is the only means. We don't have to invite the big corporations to manipulate the people sending them under the guise of investment. We have to give people to come and interact paving the way through building such initiative. The right has always double truck to react when one act.

The Right to Development though passed in $\operatorname{progress}^{5}$ has the following elements ${ }^{6}$ :

\footnotetext{
${ }^{1}$ see supra note 2. see also prof yunhu dong and prof hainan liu (2008), human right in china; human rights in chinese perspectives, china society for human rights studies

http://www.lse.ac.uk/fang-test/taiwanprogramme/events/chinahumanrights/lecture2008dongandliu.pdf

last accessed on 14 dec. 2018

${ }^{2}$ prof yunhu dong and prof hainan liu (2008), human right in china; human rights in chinese perspectives, china society for human rights studies

http://www.lse.ac.uk/fang-test/taiwanprogramme/events/chinahumanrights/lecture2008dongandliu.pdf

last accessed on 14 dec. 2018

3 ibid

${ }^{4}$ see united nation commission human right

${ }^{5}$ different resolutions were made through time and among which the un general assembly resolution no 1161(xii), the 1969 general assembly resolution 2542 (xxiv), resolution 36 (xxxvii) of 11 march 1981, united nations general assembly resolution 41/128, can be mentioned.

${ }^{6}$ united nations general assembly resolution $41 / 128$ article 1 and see also regarding chinese standing and practice of right to development on
} 
- full sovereignty over natural resources

- self-determination

- $\quad$ popular participation in the development

- equality of opportunity

- the creation of favorable conditions for the enjoyment of other civil, political, economic, social and cultural rights

These elements are important, among which, however, we are very much interested to relate the initiative with equality of opportunity. Competition when the playground doesn't allow "equal standing" is naming and developing countries need something to come equally before taking the line of equality. Among the mechanisms of pulling them is the provision of some basic services such as Road so that they could train running the development journey. Thus what the Chinese initiative stands to play is this game-providing equal opportunity to all States. Indeed, affirmative action shall be, still given to states to take the training through technology transfer, training manpower and others.

\subsection{The OBOR Initiative and China- Africa Bilateral Investment Treaty (BIT)}

China was able to play a role in Africa being a development partner and principal investor ${ }^{1}$. It was able to get deep into the heart of African people and indeed the development in African states is not without Chinese contribution ${ }^{2}$. Development in its generic form includes many things including legal development. ${ }^{3}$ As Chinese development influences Africa mutant mutandis it influences the legal system too. Especially after the link by OBOR it will be highly penetrating Africans. Especially relating to bilateral investment treaty and trade, Chinese law influence into Africa is not simple enough ${ }^{4}$. For best understand the meaning of this concept, we have taken the excerpt ${ }^{5}$ discussing Chinese investment in Africa, whether it varies from westerners. In this excerpt, it has made clear that the Chinese approach is different from the west and one can understand how China was able to influence the regional investment legal arena ${ }^{6}$. African leaders have also welcomed the Chinese approach including the very beloved historic country Ethiopia, the seat of the African Union. ${ }^{7}$

The rise in the last decade of Chinese investment in Africa continues to be a subject of curiosity. Traditionally, the bulk of foreign investment flew North-South but rarely South-South. This is changing as China becomes an important player as a sender of foreign direct investment (FDI).

In the 21 st century, international investment agreements (IIAs), particularly bilateral investment treaties (BITs), have become the principal means of protection of foreign investment. These investment treaties themselves lie along a spectrum representing the balance of power of their own era. Much like U.S. BITs, China's BITs are said to have gone through at least three generational modifications. China has employed all three generations to protect its investment in Africa. Do China's BITs tell a story of a nation's rapid transformation from a recipient of FDI to a sender of FDI? Or do they paint a more complicated picture? China's approach to investment in Africa appears to be different from the approaches that Africa's traditional partners from Europe and North America have taken over the years. A 2010 UNCTAD report describes such difference in the following terms in contrast to Africa's relationship with traditional partners, the new partnerships. Often have established forums and dialogue platforms and are generally supported by frequent high-level official visits. Furthermore, they are based on the principle of noninterference in the internal affairs of partner countries. Consequently, they are not associated with policy conditionality as has been the case in relations with traditional

zhenglimin, xinhua: the right to development: china's philosophy, practice and contribution, 12-01-2016 19:54 bjt

${ }^{1}$ lauren gamache, alexander hammer and lin jones (2013), china's trade and investment relationship with africa, usitc executive briefings on trade april 2013 see also linkages between china and sub-saharan africa as accessed from:

https://www.worldbank.org/content/dam/worldbank/gep/gep2015b/global-economic-prospects-june-2015-china-and-sub-saharan-africa.pdf

2 richard schiere (2011), china and africa: an emerging partnership for development? 2011 african development bank group https://www.afdb.org/fileadmin/uploads/afdb/documents/publications/anglaischina.pdf miria pigato and wenxia tang (2015), china and africa: expanding economic ties in an evolving global context as accessed from: https://www.worldbank.org/content/dam/worldbank/event/africa/investing\%20in \%20africa $\% 20$ forum/2015/investing-in-africa-forum-chinaand-africa-expanding-economic-ties-in-an-evolving-global-context.pdf, olufunmilayo b. arewa constructing africa: chinese investment, infrastructure deficits, and development

${ }^{3}$ see the discussion made by kidane, won; huiping, chen; feldman, on the title: reflection on china africa bits, embassy of china; chen huiping of the school of law, xiamen university; mark feldman of peking university school of transnational law; and won kidane of seattle university school of law.

${ }^{4}$ see the discussion made by kidane, won; huiping, chen; feldman, on the title: reflection on china africa bits, embassy of china; chen huiping of the school of law, xiamen university; mark feldman of peking university school of transnational law; and won kidane of seattle university school of law.

5 ibid

${ }^{6}$ j jean-pierre cabestan, « china and ethiopia: authoritarian affinities and economic cooperation », china perspectives [online], 2012/4 | 2012, online since 01 december 2015, connection on 02 may 2017. url : http://chinaperspectives.revues.org/6041

${ }^{7}$ ibid. for china the relation with ethiopia is not only an end but a means to access other countries in the south. see also hamlin, kevin, ilya gridneff, and william davison. 2014. "ethiopia becomes china's china in global search for cheap labor." bloomberg, july 22. http://www.bloomberg.com/news/2014-07-22/ethiopia-becomes-china-s-china-in-searchfor-cheap-labor.html 
partners.

The report states further that "[the] big Southern partners [mainly China] generally use official flows to promote trade and investment activities in Africa. Furthermore, Southern partners do not consider their financial contributions to other developing countries as aid. Rather they describe them as 'expressions of solidarity and cooperation bore out of shared experiences and sympathies."' Although the role of China's involvement in Africa remains a subject of great controversy and heated debate, it is clear that Africa's recent and unprecedented growth is not entirely unrelated to Chinese investment and trade. Be that as it may, China's economic interest in Africa is not all that different from Africa's traditional partners. Its means of pursuing the economic goals are also similar--although as Ambassador David Shinn puts it--China employs different tactics that might make it more acceptable to Africa. In his own words: The the United States and China use essentially the same political economic, military and cultural tools for implementing their relations with Africa. The emphasis on the two sides place on these tactics, however, and the way they implement policy varies considerably. China presents itself more humbly in its interaction with Africa. Having served as the leader of the Western world since the end of the Second World War and the only superpower since the end of the Cold War, the United States often comes across in Africa as insensitive ... The current China-Africa economic engagement is undoubtedly full of benefits and risks arguably to both sides" ${ }^{1}$. The legal infrastructure for the management of such risks is in a state of development.

This shows that the BITS, as legal framework have special Chinese character and are accepted by Africans that clearly implies Chinese positive influence on the regional investment legal order. The African now has seen the Chinese BITS models and have the exposure either to choose and further enrich this BIT to their best interest. They have got how Chinese BIT has done something good or bad and are in a position to evaluate. The BIT that the road initiative has brought about is a bit different and has a very complex feature and the fact that it touches different jurisdictions may pose something new that the Chinese could harmoniously negotiate for common consensus.

\subsection{The Essence of Chinese Equality in Investment Grant}

China is the leading overseas investor State with huge capital and human resource, its investment is extended all over the world even in the high-risk regions like Africa, Asia, and Latin America which are high-risk investment areas $^{2}$. OBOR touches those poor and neglected regions such as Africa including Pakistan ${ }^{3}$ which is politically unstable country. It attracts investors equally and invests same way all over the world without discrimination and fear of bankruptcy. Sometimes it is very clear that they are not benefiting but manifesting their internal feeling and enthusiasm for the people to develop (there may be divergent views here). It is our position that Chinese and Chinese government benefits brotherhood and friendly approach than monetary. But they may get the financial advantage in the long run. The essence of equality is deep stretching to the extent of risk sharing. This is not from liberal economic ideology as many of us can understand. The OBOR initiative, as one can see has extended into Africa which has been forgotten continent by many of the Western and American investors. It has been considered forgotten for different historical and other reasons much of which relates and attached to local administrative problems.

\subsection{The OBOR Initiative and the Principles of Integration, Cooperation}

These two principles are the pillar international principles that get opinion-juries at international level. They are fundamental international law principles applied in trade, investment, and environment. The two principles are, among other things, dominant principles in Chinese domestic legal system. The Chinese government foreign policy is also founded on these principles ${ }^{4}$.

The OBOR initiative is the landmark Chinese movement forward to the implementation of these two principles. It is very clear that for the best integration and cooperation among countries of defined territory infrastructures that unite them together is very important. And the best practical step for this is the OBOR initiative that joins more than 165 countries. The principle of cooperation is most of the time Chinese philosophy

\footnotetext{
${ }^{1}$ this excerpt is taken from article relating to chinese investment in africa titled as: china-africa investment treaties and dispute settlement: a piece of the multi-polar puzzle

these article excerpt show how the chinese approach has been accepted compared to the european and american in africa which clearly marks the chinese legal influence in investment and trade at regional level.

${ }^{2} \mathrm{kim}$, haksoon (2015) political stability and foreign direct investment, international journal of economics and finance vol. 2, no. 3; august 2010 accessed from www.ccsenet.org/ijef 17 dec. 2018

why china is sinking $\$ 46$ billion in politically unstable, terror-wracked pakistan accessed from: //economictimes.indiatimes.com/articleshow/61841843.cms?utm_source=contentofinterest\&utm_medium=text\&utm_campaign=cppst 17 dec. 2018

${ }^{4}$ see qingguo jia, from self-imposed isolation to global cooperation: the evolution of chinese foreign policy since the 1980s https://library.fes.de/pdf-files/ipg/ipg-1999-2/artjia.pdf see also david dollar, china as a global investor, https://www.brookings.edu/wpcontent/uploads/2016/07/china-as-a-global-investor_asia-working-paper-4-2.pdf
} 
and con-interference in the internal affair of states is the core of cooperation for China. Especially the principle of cooperation and integration are environmental principles of Chinese as professor Gong GU has precisely expressed in his environmental law lecture (Class lecture, $31 \mathrm{Dec} / 2017$ )

\subsection{The OBOR Initiative and Harmonization of Law}

The other tremendous effect of the OBOR initiative would be on the harmonization of laws. It is through this trend also that Chinese can best influence international legal order.

The initiative being broad spectrum as mentioned above could create an opportunity for the legal systems of different countries to converge and harmonization to come as a solution

Harmonization $^{1}$ is a process of ascertaining the admitted limits of international unification but does not necessarily amount to a vision of total uniformity. And we think the way to come through the road initiative best reflects the Chinese influence of harmonization.

\subsection{The Initiative and Chinese Foreign Policy Framework}

Another important thing that shall be seen is its foreign policy foundation that influences the majority of the world. This foreign policy of China is considered as peacebuilding document.

China established its foreign policy on three basic principles: equality, mutual benefit, and mutual respect for sovereignty and territorial integrity. Its provisional constitutional document, the Common Program, provided that the PRC should establish diplomatic relations with foreign countries on the basis of equality, mutual benefit and mutual respect for territorial sovereignty, subsequently incorporated into the first constitution of the country. They formed the basis of the Five Principles of Peaceful Coexistence in the 1950s. ${ }^{2}$

The Five Principles, a major pillar in China's foreign policy even today, were originally conceived by India's first prime minister, Jawaharlal Nehru, and China's first premier, Zhou Enlai, in 1954. The principles rose to fame at the Bandung Conference in 1955, which set the stage for the Non-Aligned Movement. The Chinese government will hold the event commemorating the sixtieth anniversary of its cherished foreign policy principles at the Great Hall of the People, The fact that Beijing chose to celebrate this anniversary with the pomp and circumstance of a state visit with two international leaders underscores the importance it continues to ascribe to the Five Principles. The Five Principles, as stated by the Panchsheel Treaty, signed on April 29, 1954, are Mutual respect for each other's territorial integrity and sovereignty, Mutual non-aggression, Mutual noninterference in each other's internal affairs, Equality and cooperation for mutual benefit, Peaceful co-existence.

The principles originally represented a vision of international relations that was highly principled and not based on realism necessarily. After Mao Zedong declared that China had "stood up" after a century of humiliation in 1949, the country needed to base its foreign policy around a set of principles that would embody its principled independence in world affairs. The Five Principles were borne of post-colonial solidarity and Chinese leaders embraced them for both their moral weight and strategic flexibility. In recent years, China continues to make reference to its principles when it comes to justifying its voting record at the United Nations Security Council or justifying its condemnation of interventionist Western powers. For China, the Five Principles' emphasis on non-intervention and respect for the sovereignty and territorial integrity of other nations are particularly important as it struggles with internal separatism in Tibet and Xinjiang. By taking a principled stand on non-intervention in all conflicts, China is able to repudiate outside criticism of its government's handling of internal affairs. This has clear message and realm of legal influence. Hegemonic intention and is a reflection of influencing the world through its foreign policy agitation.

\subsection{Negotiation, Peaceful Co-Existence and Dispute Settlement}

China is committed to peaceful settlement of international disputes and outstanding historical issues ${ }^{3}$. It has completely settled land boundary issues with 12 out of its 14 neighbors through negotiations and has resolved the issue of boundary delimitation of the Beibu Gulf with Vietnam ${ }^{4}$. China has taken a constructive part in the formulation of international rules and contributed its input on major issues concerning the interpretation, application, and development of international law. China has concluded more than 23,000 bilateral agreements, acceded to over 400 multilateral treaties and joined almost all the international organizations at the inter-

\footnotetext{
${ }^{1}$ backer, larry catá (2007) harmonizing law in an era of globalization convergence, divergence, and resistance / by larry cata backer accessed from: https://www.researchgate.net/publication/228223198

${ }^{2}$ judge xuehanqin international court of justice, china and international law: 60 years in review, chatham house 8 march 2013

${ }^{3}$ see kuan-hsiung wang, peaceful settlement of disputes in the south china sea through fisheries resources cooperation and management, contemporary asian studies series https://core.ac.uk/download/pdf/56360619.pdf, harriet moynihan, china's evolving approach to international dispute settlement, international law programme march 2017

${ }^{4}$ ramses amer, the sino-vietnamese approach to managing boundary disputes, international boundaries research unit maritime briefing volume 3 number 5. gu junfeng dispute resolution in the south china sea: from "joint development" to "joint protection" accessed from https://warwick.ac.uk/fac/soc/law/research/clusters/international/devconf/participants/papers/gu dispute resolution in the south china sea.pdf
} 
governmental level. China honors its treaty obligations in both letter and spirit in accordance with the principle of "Pacta Sunt Servanda", and takes seriously its international responsibilities. These all statements show that China has still the huge opportunity of influencing the legal order at international level. With this Chinese Stand comes OBOR initiative that connects China to more than 70 countries that imply its reach to disseminate its philosophy and influence the international legal order.

\subsection{Concluding Remarks}

China is a really big country with a great sphere of economic and investment realm as everyone can confess and its legal regime sphere of influence on the international legal order and dispute settlement is not undemanding enough. Among other things we can see the recent OBOR initiative and understand the legal influence, China can pull out its understanding of law and order to the other world. Its effort at international level in defending the developing countries interest was also bid to the extent of creating a block-South block. The initiative is being rapidly accepted as innovative road idea ever attempted which imply that the law in China has helped Chinese to well promote their creation and economic promotion not only to them but also to the whole world. It has brought about new road jurisprudence, new sovereignty idea, innovation in the right to development and contract law, links the highly forgotten continent Africa and achieves so many broad objectives. Its effective negotiation, effective dispute settlement practice, cooperation with countries of OBOR initiative, the integration and sharing equal opportunity in investment including African countries are all built in China domestic law and are founded on its foreign policy. These attempts and practices are contributing towards harmonization of law in the international arena and contribute to the international legal order. With OBOR initiative various new jurisprudences are developing in the international law development that shows China's emergence as new power in the international legal order beyond the economy. And hence the Chinese sphere of legal influence to the international legal order is vivid and hot spot area of jurisprudence that demands further study. The example of which, that the world and scholars can see, is the recent legal phenomenon of OBOR initiative among other things.

\section{References}

- backer, larry catá (2007) harmonizing law in an era of globalization convergence, divergence, and resistance / by larry cata backer accessed from: https://www.researchgate.net/publication/228223198

- $\quad$ c schachtebeck and jm mbuya (2016), assessing the potential benefits of road infrastructure development for poverty alleviation: lessons learnt from developing economies proceedings of the 35th southern african transport conference (satc 2016) https://www.researchgate.net/publication/304771228_assessing_the_potential_benefits_of_road_infrastruct ure_development_for_poverty_alleviation_lessons_learnt_from_developing_economies last accessed on 16 dec. 2018

- harriet moynihan (2017), china's evolving approach to international dispute settlement, international law programme march 2017

- helen chin, winnie he (2016), the belt and road initiative: 65 countries and beyond may 2016 accessed from

- https://www.fbicgroup.com/sites/default/files/b\%26r initiative 65 countries and beyond.pdf

- j jean-pierre cabestan (2015), « china and ethiopia: authoritarian affinities and economic cooperation », china perspectives [online], 2012/4 | 2012, online since 01 december 2015, connection on 02 may 2017. url : http://chinaperspectives.revues.org/6041

- j. unruh, m. shalaby.(2012). road infrastructure reconstruction as a peace building priority in afghanistan: negative implications for land rights, in assessing and restoring natural resources in post conflict peace building, ed. d.jensen and s. lonergan. london: earthscan. https://www.eli.org/sites/default/files/vol.5_ch.20_unruhshalaby_colorcoverpage.pdf

- judge xuehanqin (2013), international court of justice, china and international law: 60 years in review, chatham house 8 march 2013

- $\quad$ kidane, won; huiping, chen; feldman: reflection on china africa bits, embassy of china; chen huiping of the school of law, xiamen university; mark feldman of peking university school of transnational law; and won kidane of seattle university school of law.

- $\quad$ kim, haksoon (2015) political stability and foreign direct investment, international journal of economics and finance vol. 2, no. 3; august 2010 accessed from www.ccsenet.org/ijef on 17 dec. 2018

- kuan-hsiung wang, peaceful settlement of disputes in the south china sea through fisheries resources cooperation and management, contemporary asian studies series https://core.ac.uk/download/pdf/56360619.pdf,

- $\quad$ naill ferguson, in china's orbit, the wall street journal, november 18, 2010, last accessed on september 2016 http://www.wsj.com/articles/sb10001424052748704104575622531909154228, 
- $\quad$ peter cai (march 2017), understanding china's belt and road initiative, lowy institute for international policy, 2017https://www.lowyinstitute.org/sites/default/files/documents/understanding\%20china $\% \mathrm{e} 2 \% 80 \% 99 \mathrm{~s} \% 20$ belt $\% 20$ and $\% 20$ road\%20initiative_web_1.pdf last accessed on $18 \mathrm{dec} .2018$

- $\quad$ qingguo jia, from self-imposed isolation to global cooperation: the evolution of chinese foreign policy since the 1980s https://library.fes.de/pdf-files/ipg/ipg-1999-2/artjia.pdf see also david dollar, china as a global investor, https://www.brookings.edu/wp-content/uploads/2016/07/china-as-a-global-investor_asia-workingpaper-4-2.pdf

- $\quad$ ramses amer, the sino-vietnamese approach to managing boundary disputes, international boundaries research unit maritime briefing volume 3 number 5. gu junfeng dispute resolution in the south china sea: from "joint development" to "joint protection" accessed fromhttps://warwick.ac.uk/fac/soc/law/research/clusters/international/devconf/participants/papers/gu__dispute_resolution_in_the_south_china_sea.pdf

- $\quad$ sanna kopra, great power management and china's responsibility in international climate politics, jcir: vol. 4, no. 1 (2016) pp. 20-44.

- wu, xinbo. (2001), "four contradictions constraining chinaes foreign policy behavior." journal of contemporary china. 10(27): 293-301.

- $\quad$ prof yunhu dong and prof hainan liu (2008), human right in china; human rights in chinese perspectives, china society for human rights studies http://www.lse.ac.uk/fangest/taiwanprogramme/events/chinahumanrights/lecture2008dongandliu.pdf last accessed on 14 dec. 2018

- $\quad$ xi, jinping. 2012. "work together for a bright future of china-us cooperative partnership." available at http://www.fmprc.gov.cn/mfa_eng/wjdt_665385/zyjh_665391/t910351.shtml [accessed on september 24, 2018]

- $\quad$ xi, jinping. 2015. "work together to build a win-win, equitable and balanced governance mechanism on climate change." available http://www.fmprc.gov.cn/mfa_eng/wjdt_665385/zyjh_665391/t1321560.shtml. [accessed on december 16, 2018]

- xia, liping. 2001. "china: a responsible great power". journal of contemporary china. 10(26): 17-25.

- xue hanqin (judge) international court of justice, china and international law: 60 years in review, chatham house 8 march 2013

- $\quad$ xinhua (2016), the right to development: china's philosophy, practice and contribution, the state council information office of the people's republic of china december 2016

- $\quad$ zhang limin, xinhua: the right to development: china's philosophy, practice, and contribution, 12-01-2016 $19: 54 \mathrm{bj}$ 